\title{
Base cation dynamics in rainfall, throughfall, litterflow and soil solution under Oriental beech (Fagus orientalis Lipsky) trees in northern Iran
}

\author{
Maryam Moslehi ${ }^{1,2}$ (D) $\cdot$ Hashem Habashi ${ }^{2} \cdot$ Farhad Khormali $^{2} \cdot$ Akram Ahmadi $^{3} \cdot$ Ivano Brunner $^{4}$. \\ Stephan Zimmermann ${ }^{4}$ (D)
}

Received: 1 March 2019 / Accepted: 15 April 2019 / Published online: 13 May 2019

(C) INRA and Springer-Verlag France SAS, part of Springer Nature 2019

\begin{abstract}
- Key message Fluxes of base cations were studied in an Oriental beech forest and an adjacent forest gap. The fluxes of base cations in throughfall, litterflow, topsoil and subsoil solution were higher in a mixed Oriental beech forest compared to the fluxes in rainfall and topsoil and subsoil solution in the forest gap. A large proportion of cations were adsorbed or biologically immobilised by passing through the litter layer in the forest. In the mineral topsoil, a new equilibrium between the solid phase

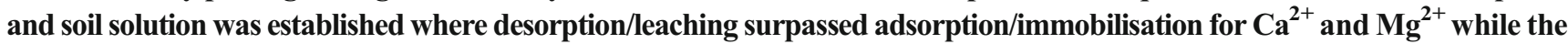
opposite was true for $\mathrm{K}^{+}$. The contribution of throughfall is considerable in biogeochemical cycling.

- Context Although it is important to measure nutrient fluxes to establish forest soil chemical fertility, little data is available for Oriental beech forests, one of the most important commercial hardwood forests in Iran. The quantification of nutrient fluxes above and below ground is essential because nutrients in the soil solution are most easily available for tree uptake. A thorough understanding of biogeochemical nutrient cycling requires an investigation of nutrient fluxes between different compartments. - Aims We evaluated the effect of Oriental beech forests on biogeochemical cycling of $\mathrm{Ca}^{2+}, \mathrm{Mg}^{2+}, \mathrm{K}^{+}$and $\mathrm{Na}^{+}$by analysing their fluxes in rainfall, throughfall, litterflow and soil solution.

- Methods Throughfall, litterflow and soil solution were sampled during one whole year under five Oriental beech trees in a mixed Hyrcanian beech forest. The amounts of $\mathrm{Ca}^{2+}, \mathrm{Mg}^{2+}, \mathrm{K}^{+}$and $\mathrm{Na}^{+}$in these fluxes were calculated based on their concentrations and the sampled volumes and subsequently compared with the respective fluxes in the rainfall and soil solution of an adjacent forest gap.

- Results We found significantly higher fluxes in all the measured base cations in throughfall compared to rainfall. Entering the litter layer in the forest, nearly $50 \%$ of the dissolved base cations adsorb to the solid phase or are biologically immobilised prohibiting their leaching to deeper soil horizons. In the mineral soil, the interactions between the solid phase and soil solution were comparable between the forest and the forest gap.

- Conclusion This study highlights the role of interactions of rainwater with tree crowns and the litter layer in biogeochemical cycling and emphasises its importance for the maintenance of soil chemical fertility in Oriental beech forests.
\end{abstract}

\section{Handling Editor: Erwin Dreyer}

Contribution of the co-authors MM, HH, FK and AA developed the overall research idea, coordinated data collection and laboratory analyses. MM analysed the data with contributions from IB and SZ. MM, IB and SZ wrote the paper with contributions and input from all authors.

Stephan Zimmermann

stephan.zimmermann@wsl.ch

1 Research Division of Natural Resources, Hormozgan Agriculture and Natural Resources Research and Education Center, AREEO, Bandarabbas, Iran

2 Faculty of Gorgan University of Agricultural Science and Natural Resources, I.R.I Iran, Gorgan University, Gorgan, Islamic Republic of Iran
3 Research Division of Natural Resources, Golestan Agricultural and Natural Resources Research and Education Center, AREEO, Gorgan, Iran

4 Swiss Federal Institute for Forest, Snow and Landscape Research WSL, Birmensdorf, Switzerland 
Keywords Biogeochemical cycling $\cdot$ Calcium $\cdot$ Magnesium $\cdot$ Potassium $\cdot$ Fagus orientalis Lipsky

\section{Introduction}

Base cations as part of the nutrient cycles in forests are tightly related to the hydrological cycle because water acts as the main solvent and transporting agent for nutrient elements between aboveground tree stands and the soil underneath (Bruijnzeel 2001). The composition of rainfall (RF) passing through a forest canopy and litter is generally altered because of interdependencies between dry deposition and rainfall, as well as ion-exchange processes depending on concentration gradients between canopy surfaces and rainwater (Schaefer et al. 1988). Furthermore, the strength of these processes depends on the biological activity of microorganisms, phenological phases, tissue exudation and decomposition (Návar et al. 2009). Soils in the environment support the growth of plants. The plants absorb the moisture and nutrients used for their growth and development from the soil. In the whole nutrient cycle, not only does the nutrient uptake play an important part, but also the leaching of nutrients from the plant biomass by precipitation and its return to the soil (Ward and Robinson 2000). Nutrients returned to the soil through stemflow, throughfall (TF) and litterfall help to maintain soil fertility by increasing the quantities of nutrients in the soil (Muoghalu and Oakhumen 2000).

Several studies have found that throughfall was enriched by base cations (especially $\mathrm{K}^{+}$) compared to rainfall in all sorts of different forest types, which is related to foliage and canopy leaching or atmospheric deposition (Potter 1991; Staelens et al. 2003; Chuyong et al. 2004; Tobón et al. 2004a; Fujinuma et al. 2005; Dezzeo and Chacón 2006; Duchesne and Houle 2006; Adedeji and Gbadegesin 2012). Analogous investigations have been carried out in temperate forests which showed substantial leaching of the base cations potassium $\left(\mathrm{K}^{+}\right)$, calcium $\left(\mathrm{Ca}^{2+}\right)$ and magnesium $\left(\mathrm{Mg}^{2+}\right)$ from the canopy by throughfall compared to other cations (Potter 1991; Staelens et al. 2008; André et al. 2008; Van Stan et al. 2012). Leaching of base cations is affected, amongst other factors, by canopy structure, climate and the nutritional state of trees (Staelens et al. 2003).

Liu et al. (2002) found that base cation concentrations and fluxes were higher in throughfall relative to rainfall. They also reported that most $\mathrm{K}^{+}$and two-thirds of $\mathrm{Mg}^{2+}$ in throughfall was due to canopy leaching. Fujinuma et al. (2005) investigated species-related differences in nutrient cycling. They reported that $\mathrm{K}^{+}$had the greatest leaching in throughfall for all tree species while $\mathrm{Ca}^{2+}$ was the dominant cation in the forest floor leachate beneath basswood (Tilia americana L.) and hemlock (Tsuga canadensis $\mathrm{L}$.), and $\mathrm{K}^{+}$and $\mathrm{Ca}^{2+}$ had equally high leaching for sugar maple (Acer saccharum Marsh.). Base cation release from litter leaching (litterflow, LF) is associated with degradation rate and quality of leaf litter, as demonstrated by numerous studies (Strobel et al. 2001; Van Nevel et al. 2013). Generally, concentrations of elements in both litterflow and throughfall follow the same pattern. Element outputs from litterflow were found to be strongly associated with the inputs from throughfall. In most cases, the average concentrations of nutrients such as $\mathrm{K}$, $\mathrm{Mg}, \mathrm{P}$ and the $\mathrm{pH}$ of litterflow were lower than those in throughfall (Tobón et al. 2004b). After the entry of litterflow into the mineral soil-a multicomponent system consisting of solid, liquid and gaseous phases - a new equilibrium state between these three phases is established. The cation exchange equilibrium is affected mostly by the distribution of cations between the solid and solution phase (Evangelou and Phillips 2005). The predominantly negative charge of soil colloids represents a huge reaction surface for cation adsorption which will potentially affect the chemical composition of litterflow entering the mineral soil.

Caspian forests, with an area of about 2,000,000 ha, are located between-20 and $2200 \mathrm{~m}$ a.s.l. in northern Iran. Pure and mixed beech stands are amongst the most important and richest stands of Hyrcanian forests. Beech forests cover about 17.4\% of Iran's forests (Parsapajouh 1974), and Oriental beech (Fagus orientalis Lipsky) is one of the most important commercial hardwood species in Iranian forestry. Although many studies have been conducted throughout the world related to nutrient cycling by throughfall and stemflow, only a few studies have been done in relation to leached nutrients of litter and soil in forests dominated by Oriental beech. Abbasian et al. (2014) measured some nutrients in throughfall and gross rainfall in Oriental beech forests and found the average enrichment of $\mathrm{K}^{+}$in throughfall to be the highest. Salehi et al. (2016) concluded that concentrations of nutrients, and in particular $\mathrm{K}^{+}$, in Oriental beech stands were generally higher in throughfall relative to rainfall. These investigations did not consider the chemistry of the soil solution and the role of the litter layer, however. Therefore, the present study compares the chemistry of the aboveground water fluxes passing through the tree canopy with the chemistry of the soil solution in a mixed stand of Oriental beech in Northern Iran as well as the analysed rainfall and soil solution of a nearby forest gap. It was expected that (1) throughfall in Oriental beech forests is significantly enriched with nutrient cations $(\mathrm{K}, \mathrm{Na}, \mathrm{Mg}, \mathrm{Ca})$ and that the annual input to the soil of these base cations by throughfall is significantly higher compared to the annual input by rainfall into the forest gap, (2) litterflow is depleted with base cations compared to throughfall due to exchange processes in the litter layer where adsorption and biological fixation predominates, (3) the fluxes of base cations in the mineral soil are significantly higher in the forest compared to the forest gap and (4) with increasing percolation depth in the mineral soil, the concentrations of base cations in the soil solution will further decrease due to the high adsorption capacity of the soil matrix. 


\section{Materials and methods}

\subsection{Site description}

This study was conducted in a mixed natural Hyrcanian beech forest within district one (parcel 17 and 18) at the Shastkolate Forest Research Station of the University of Gorgan, located $5 \mathrm{~km}$ southwest of Gorgan, Golestan Province ( $36^{\circ} 43^{\prime} \mathrm{N} / 54^{\circ}$ $21^{\prime}$ E), northern Iran. District one covers approximately $1713.3 \mathrm{ha}$ and its elevation ranges from 210 to $995 \mathrm{~m}$ a.s.l. The ground slope ranges from 0 to $80 \%$. Mean annual precipitation is $649 \mathrm{~mm}$ ranging from 528 to $817 \mathrm{~mm}$. The climate is moderately humid with an annual mean temperature of $15.4{ }^{\circ} \mathrm{C}$. The area is dominated by natural temperate forests containing native mixed deciduous tree species such as Oriental beech (Fagus orientalis Lipsky), hornbeam (Carpinus betulus L.), Persian maple (Acer velutinum Boiss.), Persian ironwood (Parrotia persica (DC.) C.A.Mey.), Caucasian alder (Alnus subcordata C.A.Mey.) and black alder (Alnus glutinosa (L.) Gaertn.) (Moslehi 2010). The existing soil types are umbric fluvisols and chromic cambisols (IUSS Working Group WRB 2006).

A rectangular sample plot with an area of 0.5 ha and covered with a mixed stand of Fagus orientalis was selected at the border of parcel 17 and 18 . The tree density in the sample plot was 96 trees $\mathrm{ha}^{-1}$, with tree diameters varying from 7.5 to $105 \mathrm{~cm}$ and a canopy cover of $85 \%$. The dominant tree species in the upper layer are Oriental beech (Fagus orientalis Lipsky) and hornbeam (Carpinus betulus L.). Additionally, Persian maple (Acer velutinum Boiss.) and Persian ironwood (Parrotia persica (DC.) C.A.Mey.) make up part of the forest stand. The understory vegetation is composed of Rubus fruticosus L., Viola reichenbachiana Boreau, Ruscus hyrcanus Woronow and Pteridium aquilinum (L.) Kuhn. The composition of the vegetation corresponds with the phytosociological unit of a Fageto-Carpinetum. The parent material is limestone, the soil texture is a silty clay loam and the elevation and slope of the sample plot are $550 \mathrm{~m}$ a.s.l. and $35 \%$ on average (highly variable), respectively (Moslehi 2010).

\subsection{Field measurements}

Five healthy and dominant beech trees with the same ecological conditions (topography, parent material, soil texture) were selected in the overstory of the sample plot. The selected trees did not overlap with adjacent trees (free canopy cover) in order to estimate the effect of canopy throughfall on base cation dynamics. The sample trees had a mean crown area of $221 \mathrm{~m}^{2}$, a mean volume of $10.8 \mathrm{~m}^{3}$, a mean basal area of $0.63 \mathrm{~m}^{2}$, a mean diameter at breast height of $89 \mathrm{~cm}$ and a mean height of $34.6 \mathrm{~m}$ (Table 1). As a comparison reference to the forest stand, an open area in a forest gap with an area of
Table 1 Allometric properties of Oriental beech trees in the mixed Hyrcanian beech stand

\begin{tabular}{llllll}
\hline Tree no. & $\begin{array}{l}\text { Crown area } \\
\left(\mathrm{m}^{2}\right)\end{array}$ & $\begin{array}{l}\text { Volume } \\
\left(\mathrm{m}^{3}\right)\end{array}$ & $\begin{array}{l}\text { Basal area } \\
\left(\mathrm{m}^{2}\right)\end{array}$ & $\begin{array}{l}\text { D.B.H. } \\
(\mathrm{cm})\end{array}$ & $\begin{array}{l}\text { Height } \\
(\mathrm{m})\end{array}$ \\
\hline 1 & 268 & 11.8 & 0.55 & 84 & 42.9 \\
2 & 150 & 6.3 & 0.38 & 70 & 33.0 \\
3 & 222 & 9.1 & 0.62 & 89 & 29.4 \\
4 & 150 & 11.9 & 0.86 & 105 & 27.7 \\
5 & 313 & 14.9 & 0.75 & 98 & 39.8 \\
Mean & 221 & 10.8 & 0.63 & 89 & 34.6 \\
\hline
\end{tabular}

D.B.H, Diameter at breast height

$980 \mathrm{~m}^{2}$ located $70 \mathrm{~m}$ away from the forest sample plot was chosen to measure rainfall as bulk precipitation.

Stemflow was not measured in the forest stand because it contributes only $0.3 \%$ to the total precipitation in beech forests in Shastkolate (Ghorbani and Rahmani 2009). The portion of incidental rainfall which passes through the canopy, either directly in gaps or after interacting with foliage and branches, is defined as throughfall (Parker 1983). The portion of throughfall which passes through the litter on the forest floor is defined as litterflow (Moslehi 2010). Rainfall (RF), throughfall (TF), litterflow (LF), topsoil and subsoil solution in the forest (TSF, SSF) and in the forest gap (TSO, SSO) were sampled monthly during an entire year from December 21, 2008 to December 21, 2009, comprising in total 32 rainfall events and one snowfall event (Fig. 1). For the sampling of throughfall, 20 cylindrical plastic collectors $(23 \mathrm{~cm}$ in height, $7.75 \mathrm{~cm}$ in diameter) were randomly installed under each tree (fixed to a wooden peg $20 \mathrm{~cm}$ above the forest ground). In the forest gap, rainfall was collected with 20 galvanised rustproof containers ( $20 \mathrm{~cm}$ in diameter, $50 \mathrm{~cm}$ in height). A nylon mesh was placed at the opening of all collectors to prevent contamination by coarse debris. The collectors were emptied after each rainfall and rinsed with distilled water before being replaced.

Litterflow was sampled under each tree with ten randomly distributed cylindrical gauges $(11.5 \mathrm{~cm}$ in height, $8 \mathrm{~cm}$ in diameter) under each tree, buried even with the ground and covered with a metal mesh. Freshly and previously fallen litter from beside the installed collectors was put on the metal mesh with a thickness of 2 to $5 \mathrm{~cm}$ (corresponding to the real thickness of the litter layer).

Under each of the sample trees in the forest, one soil profile was dug at a distance of at least $1 \mathrm{~m}$ from the trunk to a depth of 120 to $170 \mathrm{~cm}$ (Table 2). The physical characterisation of the profiles followed the Soil Survey Staff (2010) and Schoeneberger et al. (2012). In every soil profile, zerotension lysimeters (galvanised rustproof containers, $5 \times$ $5 \mathrm{~cm}$ ) were installed in two depths, directly at the lower edge of the topsoil $(0-10 \mathrm{~cm})$ and in the subsoil $(10-50 \mathrm{~cm})$. An 


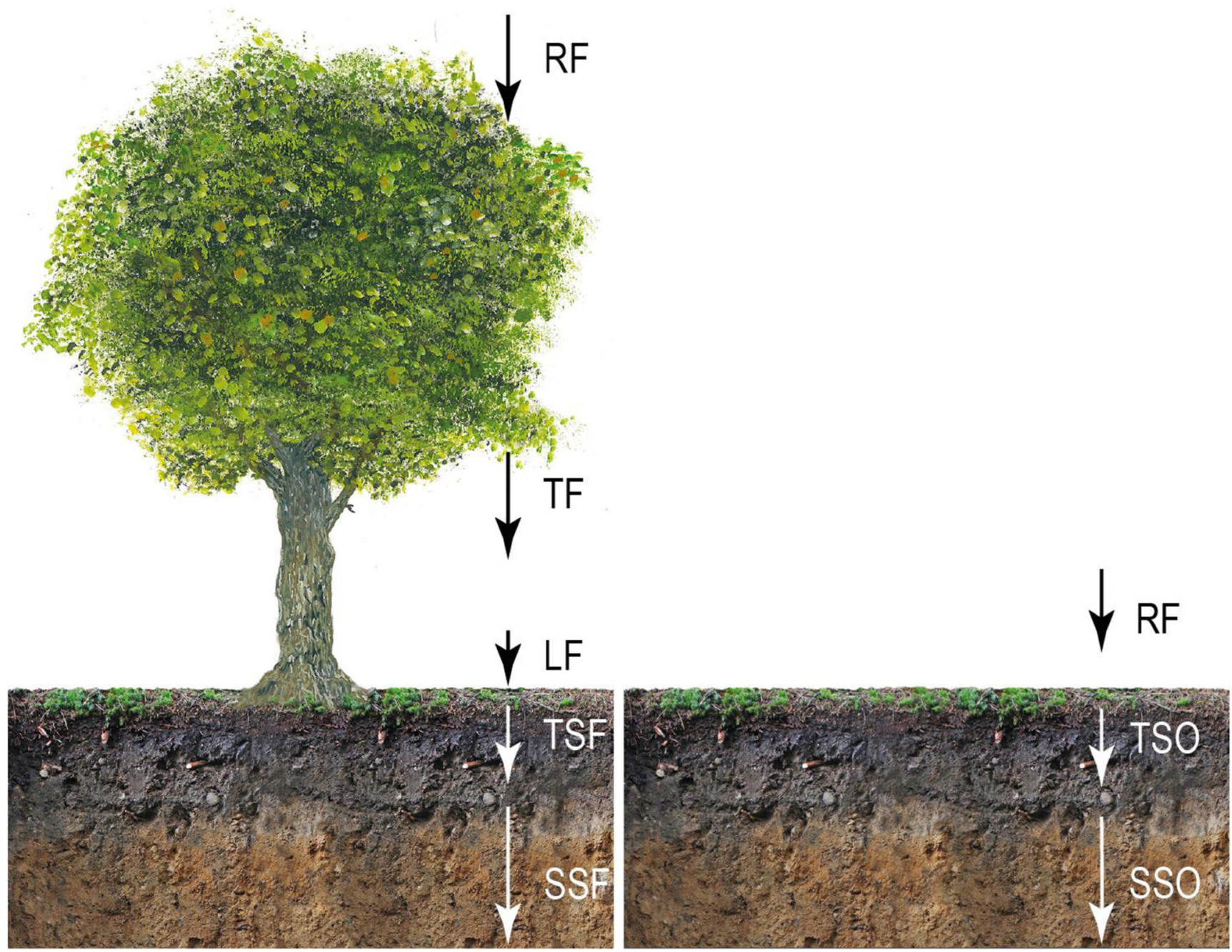

Fig. 1 Schematic representation of the fluxes in the forest (left) and the forest gap (right). RF, rainfall; TF, throughfall; LF, litterflow; TSF, topsoil leaching forest; SSF, subsoil leaching forest; TSO, topsoil leaching forest gap; SSO, subsoil leaching forest gap

additional soil profile was dug in the forest gap to a depth of $160 \mathrm{~cm}$ (Table 2). Here, five zero-tension lysimeters (galvanised rustproof containers, $5 \times 5 \mathrm{~cm}$ ) were installed independently of each other at the lower edge of the topsoil ( 0 $10 \mathrm{~cm})$ and the subsoil $(10-50 \mathrm{~cm})$. The lysimeters were connected to a 1-L plastic bottle via a discharge unit at the lowermost end and a flexible plastic tube (diameter $1 \mathrm{~cm}$ ). Soil solution and litterflow were collected after each rain event.

\subsection{Laboratory analysis}

Physical and chemical soil properties in the forest and the forest gap were analysed from 12 samples of the topsoil and the subsoil. Soil samples were taken at the soil profiles at the depths of $0-10 \mathrm{~cm}$ and $10-50 \mathrm{~cm}$ and put into polyethylene bags for transportation to the laboratory. All samples were air-dried and sieved with a 1-mm mesh and analysed for $\mathrm{pH}$, organic matter, $\mathrm{CaCO}_{3}$ and soil texture. The analyses were made in triplicate. For each property, an internal reference soil was included in the analysis. Soil $\mathrm{pH}$ was measured potentiometrically (Smith and Doran 1996) in $0.01 \mathrm{M} \mathrm{CaCl}_{2}$ (solid:solution $=1: 2$, under stirring after 30 -min extraction time), $\mathrm{CaCO}_{3}$ with calcimetry (Zarinkafsh 1992), organic matter using the Walkley-Black method (Nelson and Sommers 1996) and soil texture using the hydrometer method (Gee and Bauder 1986).

The volumes of soil solution collected were measured using a graduated cylinder, and the soil solutions were stored at $4{ }^{\circ} \mathrm{C}$. The concentrations of base cations were measured on all water samples. $\mathrm{Na}^{+}$and $\mathrm{K}^{+}$concentrations were measured using flame photometry (PFP7 Jenway, Staffordshire, UK) (Smith and Doran 1996), and $\mathrm{Ca}^{2+}$ and $\mathrm{Mg}^{2+}$ concentrations were measured using atomic absorption spectrophotometry (UNICAM 919, Cambridge, UK) (Dewis and Freitas 1970). Standard solutions of titanium and lanthanum (LabKings, AA Grade $10 \mathrm{mg} / \mathrm{l})$ served as internal standards. Annual amounts of 
the base cations in the various fluxes were calculated by multiplying the concentrations by the respective water volumes. The annual amount of soil solution was calculated based on the measured volumes of the soil solution.

\subsection{Statistical analysis}

The normality of variables and equality of variances was checked using the Kolmogorov-Smirnov and Levene's tests. Differences in the flux of the base cations between rainfall and throughfall, rainfall and litterflow, topsoil solution of forest and forest gap and subsoil solution of forest and forest gap were tested for significance using the $t$ test. Significant statistical differences determined at the $95 \%$ confidence level were adjusted by applying the Bonferroni correction $(\alpha / 4$ or 0.0125). The Bonferroni correction was used to reduce the risk of type 1 errors. All statistical analyses were performed with the software package SPSS 20 for Windows (IBM Corp.
Released 2011. IBM SPSS Statistics for Windows, Version 20.0. Armonk, NY).

\section{Results}

\subsection{Soil chemical and physical characteristics}

In all soil profiles, the soil texture of the topsoil and subsoil was silty clay loam and clay, respectively, with no differences between the forest soil and the soil of the forest gap (Table 2). In the forest gap, higher $\mathrm{pH}$ values and $\mathrm{CaCO}_{3}$ content in the soils were observed compared to the forest sites, which means that under the canopies of Fagus orientalis the $\mathrm{pH}$ values of the topsoil and the subsoil were about one $\mathrm{pH}$ unit lower than in the forest gap (Table 2). The mean organic matter content in the forest topsoil was, at about $7.0 \%$, distinctly higher compared to the forest subsoil, at around $2.9 \%$. In the forest gap,

Table 2 Physical and chemical properties of soil horizons in the forest and in the forest gap (according to the Soil Survey Staff 2010)

\begin{tabular}{|c|c|c|c|c|c|c|c|c|c|c|c|}
\hline Soil profile & Horizon & Depth (cm) & Structure & Colour & $\mathrm{pH}\left(\mathrm{CaCl}_{2}\right)$ & $\mathrm{CaCO}_{3}(\%)$ & $\mathrm{OM}(\%)$ & Clay (\%) & Sand (\%) & Silt (\%) & Texture \\
\hline \multirow[t]{4}{*}{ Tree 1} & A & $0-9$ & gr & 10YR3/2 & 6.5 & 1.0 & 7.4 & 36 & 5.6 & 58 & $\mathrm{SiCL}$ \\
\hline & Bw1 & $9-50$ & $2 \mathrm{msbk}$ & $10 \mathrm{YR} 4 / 3$ & 7.2 & 26.0 & 3.1 & 61 & 2.9 & 36 & $\mathrm{C}$ \\
\hline & Bw2 & $50-80$ & $2 \mathrm{msbk}$ & $7.5 \mathrm{YR} 3 / 3$ & - & - & - & - & - & - & - \\
\hline & $\mathrm{Bt}$ & $80-120$ & $2 \mathrm{cabk}$ & $7.5 \mathrm{YR} 3 / 3$ & - & - & - & - & - & - & - \\
\hline \multirow[t]{4}{*}{ Tree 2} & A & $0-8$ & $\mathrm{gr}$ & 10YR4/2 & 6.7 & 1.0 & 6.2 & 28 & 13.8 & 58 & SiCL \\
\hline & $\mathrm{Bw}$ & $8-40$ & $2 \mathrm{fabk}$ & $7.5 \mathrm{YR} 4 / 3$ & 6.9 & 30.0 & 3.4 & 52 & 13.8 & 34 & $\mathrm{C}$ \\
\hline & $\mathrm{Bt}$ & $40-89$ & $2 \mathrm{mabk}$ & 5YR3/3 & - & - & - & - & - & - & - \\
\hline & Bss & 89-130 & $3 \mathrm{cpr}$ & $7.5 \mathrm{YR} 3 / 3$ & - & - & - & - & - & - & - \\
\hline \multirow[t]{5}{*}{ Tree 3} & $\mathrm{~A}$ & $0-5$ & gr & 10YR3/2 & 6.6 & 5.5 & 6.7 & 31 & 11.0 & 58 & SiCL \\
\hline & $\mathrm{Bg} 1$ & $5-38$ & 1 fabk & $7.5 \mathrm{YR} 4 / 4$ & 6.5 & 13.0 & 2.2 & 59 & 2.8 & 38 & $\mathrm{C}$ \\
\hline & $\mathrm{Bg} 1$ & $38-70$ & 2 mabk & $7.5 \mathrm{YR} 3 / 3$ & - & - & - & - & - & - & - \\
\hline & $\mathrm{Bg} 2$ & $70-100$ & $2 \mathrm{cabk}$ & 5YR3/3 & - & - & - & - & - & - & - \\
\hline & $\mathrm{Bt}$ & $100-130$ & 3 cabk & $5 \mathrm{YR} 3 / 3$ & - & - & - & - & - & - & - \\
\hline \multirow[t]{4}{*}{ Tree 4} & A & $0-5$ & gr & 10YR3/2 & 6.6 & 5.5 & 8.2 & 31 & 11.0 & 58 & $\mathrm{SiCL}$ \\
\hline & $\mathrm{Bw}$ & $5-45$ & $3 \mathrm{msbk}$ & $7.5 \mathrm{YR} 4 / 3$ & 6.9 & 28.5 & 3.2 & 26 & 5.6 & 32 & $\mathrm{C}$ \\
\hline & Bt1 & $45-90$ & $3 \mathrm{csbk}$ & $2.5 \mathrm{YR} 3 / 3$ & - & - & - & - & - & - & - \\
\hline & Bt2 & $90-120$ & 2 mabk & $5 \mathrm{YR} 4 / 4$ & - & - & - & - & - & - & - \\
\hline \multirow[t]{5}{*}{ Tree 5} & A & $0-8.5$ & gr & 10YR3/3 & 7.2 & 12.5 & 6.7 & 33 & 11.0 & 56 & $\mathrm{SiCL}$ \\
\hline & $\mathrm{Bw}$ & $8.5-37$ & $2 \mathrm{msbk}$ & 10YR4/3 & 6.9 & 25.5 & 2.8 & 60 & 8.3 & 32 & $\mathrm{C}$ \\
\hline & Bt1 & $37-75$ & 3 cabk & $7.5 \mathrm{YR} 4 / 3$ & - & - & - & - & - & - & - \\
\hline & Bt2 & $75-130$ & $3 \mathrm{cabk}$ & $7.5 \mathrm{YR} 4 / 3$ & - & - & - & - & - & - & - \\
\hline & $\mathrm{Bk}$ & $130-170$ & $2 \mathrm{mabk}$ & 10YR4/4 & - & - & - & - & & - & - \\
\hline \multirow[t]{5}{*}{ Open area } & $\mathrm{A}$ & $0-10$ & gr & 10YR3/2 & 7.7 & 23.0 & 2.0 & 30 & 16.5 & 54 & $\mathrm{SiCL}$ \\
\hline & Bw1 & $10-45$ & $2 \mathrm{mabk}$ & $7.5 \mathrm{YR} 4 / 3$ & 7.8 & 30.0 & 1.6 & 50 & 13.8 & 36 & $\mathrm{C}$ \\
\hline & Bw2 & $45-85$ & $2 \mathrm{mabk}$ & $7.5 \mathrm{YR} 4 / 3$ & - & - & - & - & - & - & - \\
\hline & Bw3 & $85-115$ & 3 mabk & $2.5 \mathrm{YR} 4 / 3$ & - & - & - & - & - & - & - \\
\hline & Bw4 & $115-160$ & $1 \mathrm{cabk}$ & $5 Y R 4 / 3$ & - & - & - & - & & - & - \\
\hline
\end{tabular}

$g r$, granular; $a b k$, angular blocky; $s b k$, sub-angular blocky; $p r$, prismatic; $f$, fine; m, medium; $c$, coarse; Si, silt; $C$, clay; $C L$, clay loam; $O M$, organic matter 
organic matter content was distinctly lower (topsoil $2.0 \%$, subsoil 1.6\%; Table 2).

\subsection{Annual base cation inputs in rainfall, throughfall and litterflow}

Single precipitation events in the forest gap (rainfall) ranged from $26 \mathrm{~mm}$ in spring to $127 \mathrm{~mm}$ in summer and accumulated to $970 \mathrm{~mm}$ for the whole observation period. The contribution of throughfall and litterflow to the total rainfall was $709 \mathrm{~mm}$ $(73 \%)$ and $316 \mathrm{~mm}(33 \%)$, respectively (Table 3). Potassium was the dominant element in the base cation fluxes in rainfall, throughfall and litterflow, followed by $\mathrm{Na}^{+}, \mathrm{Ca}^{2+}$ and $\mathrm{Mg}^{2+}$ (Table 3 ). The annual inputs of all these base cations in throughfall were significantly higher than in rainfall, with $\Delta$ TF-RF $=16.8 \mathrm{~kg} \mathrm{ha}^{-1}$ year $^{-1}\left(64 \%\right.$ of RF) for $\mathrm{Na}^{+}$, $57.4 \mathrm{~kg} \mathrm{ha}^{-1}$ year $^{-1}(105 \%)$ for $\mathrm{K}^{+}, 18.5 \mathrm{~kg} \mathrm{ha}^{-1}$ year $^{-1}$ (196\%) for $\mathrm{Ca}^{2+}$ and $2.9 \mathrm{~kg} \mathrm{ha}^{-1}$ year $^{-1}$ (91\%) for $\mathrm{Mg}^{2+}$ $(P<0.05$; Table 3$)$. The ratios of TF/RF were highest for $\mathrm{Ca}^{2+}$ (2.9), followed by $\mathrm{K}^{+}(2.1)$ and $\mathrm{Mg}^{2+}(1.9)$ and lowest for $\mathrm{Na}^{+}$(1.6; Table 4). With the exception of $\mathrm{Na}^{+}$, the annual fluxes in litterflow were also higher than in rainfall. However, the difference was only significant for $\mathrm{Ca}^{2+}$ (Table 3). The ratios of $\mathrm{LF} / \mathrm{TF}$ in decreasing order were $\mathrm{Mg}^{2+}(0.7), \mathrm{K}^{+}$ (0.6) and $\mathrm{Ca}^{2+}$ and $\mathrm{Na}^{+}(0.5)$. Thus, the element fluxes in throughfall were approximately twice as high as those in litterflow (Table 4).

\subsection{Base cation leaching in soil solutions}

The volume of water which percolated through the topsoil in the forest was $129 \%$ of the volume which passed through the
Table 4 Ratios between fluxes of base cations in the forest and the forest gap

\begin{tabular}{llllll}
\hline Site & Flux ratio & $\mathrm{Na}^{+}$ & $\mathrm{K}^{+}$ & $\mathrm{Ca}^{2+}$ & $\mathrm{Mg}^{2+}$ \\
\hline Forest & TF/RF & 1.6 & 2.1 & 2.9 & 1.9 \\
& LF/TF & 0.5 & 0.6 & 0.5 & 0.7 \\
& TSF/LF & 1.6 & 0.7 & 2.6 & 1.7 \\
& SSF/TSF & 1.0 & 0.6 & 1.0 & 0.9 \\
Forest gap & TSO/RF & 1.2 & 0.6 & 6.0 & 1.8 \\
& SSO/TSO & 0.6 & 0.5 & 0.6 & 0.5 \\
\hline
\end{tabular}

$R F$, rainfall; $T F$, throughfall; $L F$, litterflow; $T S F$, topsoil leaching forest; $S S F$, subsoil leaching forest; TSO, topsoil leaching forest gap; SSO, subsoil leaching forest gap

litter layer, and in the subsoil, it was $82 \%$ of the volume which percolated through the topsoil (Table 3). Interestingly, more water percolated through the forest soil compared to the forest gap soil at both depths. In the forest gap, 34\% of rainfall percolated through the topsoil and, of this amount, $73 \%$ percolated through the subsoil (Table 3).

With the exception of $\mathrm{Ca}^{2+}$, the annual leaching of base cations from the forest topsoil was higher than the leaching in the forest gap, whereas the difference was only significant for $\mathrm{K}^{+}$(Table 3 ). The ratios of TSF/LF in the forest were highest for $\mathrm{Ca}^{2+}$ (2.6), moderate for $\mathrm{Mg}^{2+}$ (1.7) and $\mathrm{Na}^{+}$ (1.6), and lowest for $\mathrm{K}^{+}(0.7)$ (Table 4). In the subsoil, $\mathrm{Na}^{+}$ and $\mathrm{K}^{+}$leaching was significantly higher in the forest compared to the forest gap, whereas there was no or only a small insignificant difference in the leached amounts for $\mathrm{Ca}^{2+}$ and $\mathrm{Mg}^{2+}$. In the soil solutions of the subsoil of the forest, and in the topsoil and subsoil of the forest gap, the leached amounts

Table 3 Mean annual inputs of water and base cations (mean $\pm \mathrm{SE} ; N=5$ ) in the forest and the forest gap, with comparisons of fluxes between the forest and the forest gap

\begin{tabular}{|c|c|c|c|c|c|c|}
\hline Site & Flux section & Water $\left(\mathrm{mm}\right.$ year $\left.^{-1}\right)$ & $\mathrm{Na}^{+}$ & $\mathrm{K}^{+}\left(\mathrm{kg} \mathrm{ha}^{-1}\right.$ year $\left.^{-1}\right)$ & $\mathrm{Ca}^{2+}$ & $\mathrm{Mg}^{2+}$ \\
\hline \multirow[t]{5}{*}{ Forest } & $\mathrm{RF}$ & $970 \pm 7.6$ & $26.3 \pm 0.5$ & $54.6 \pm 1.5$ & $9.5 \pm 0.4$ & $3.2 \pm 0.2$ \\
\hline & $\mathrm{TF}$ & $709 \pm 26.5$ & $43.1 \pm 1.2$ & $112.1 \pm 6.9$ & $28.1 \pm 2.4$ & $6.1 \pm 0.7$ \\
\hline & $\mathrm{LF}$ & $316 \pm 22.4$ & $21.3 \pm 1.6$ & $65.8 \pm 5.6$ & $14.2 \pm 1.1$ & $4.5 \pm 0.3$ \\
\hline & TSF & $408 \pm 20.7$ & $33.3 \pm 1.9$ & $49.1 \pm 4.0$ & $36.4 \pm 2.3$ & $7.7 \pm 0.9$ \\
\hline & SSF & $336 \pm 27.5$ & $31.8 \pm 2.9$ & $31.8 \pm 2.6$ & $35.2 \pm 6.3$ & $6.6 \pm 1.0$ \\
\hline \multirow[t]{3}{*}{ Flux differences } & & $\Delta \mathrm{TF}-\mathrm{RF}$ & $16.8^{*}$ & $57.4^{*}$ & $18.6^{*}$ & $2.9^{*}$ \\
\hline & & $\Delta \mathrm{LF}-\mathrm{TF}$ & $-21.8^{*}$ & $-66.3^{*}$ & $-13.9^{*}$ & $-1.6^{*}$ \\
\hline & & $\Delta \mathrm{LF}-\mathrm{RF}$ & -5.0 & 11.2 & $4.7^{*}$ & 1.3 \\
\hline \multirow[t]{3}{*}{ Forest gap } & $\mathrm{RF}$ & $970 \pm 7.6$ & $26.3 \pm 0.5$ & $54.6 \pm 1.5$ & $9.5 \pm 0.4$ & $3.2 \pm 0.2$ \\
\hline & TSO & $327 \pm 10.1$ & $31.3 \pm 0.9$ & $30.4 \pm 0.9$ & $56.9 \pm 1.6$ & $5.7 \pm 0.3$ \\
\hline & $\mathrm{SSO}$ & $239 \pm 15.1$ & $19.2 \pm 0.8$ & $15.5 \pm 0.5$ & $36.5 \pm 2.8$ & $2.8 \pm 0.1$ \\
\hline \multirow[t]{2}{*}{ Flux differences } & & $\Delta$ TSF-TSO & 2.0 & $18.7 *$ & -20.5 & 2.0 \\
\hline & & $\Delta \mathrm{SSF}-\mathrm{SSO}$ & $12.6^{*}$ & $16.3^{*}$ & -1.3 & 3.8 \\
\hline
\end{tabular}

(*Significant at $P<0.05) . R F$, rainfall; $T F$, throughfall; $L F$, litterflow; $T S F$, topsoil leaching forest; $S S F$, subsoil leaching forest; TSO, topsoil leaching forest gap; SSO, subsoil leaching forest gap 
of base cations were in decreasing order: $\mathrm{Ca}^{2+}>\mathrm{Na}^{+} \approx \mathrm{K}^{+}>$ $\mathrm{Mg}^{2+}$. Only in the topsoil of the forest, $\mathrm{K}^{+}$was highest, followed by $\mathrm{Ca}^{2+}, \mathrm{Na}^{+}$and $\mathrm{Mg}^{2+}$ (Table 3). The ratios of $\mathrm{SSF} / \mathrm{TSF}$ and SSO/TSO were all between 0.5 and 1.0, with the highest values for $\mathrm{Ca}^{2+}$ and $\mathrm{Na}^{+}$, and the lowest values for $\mathrm{Mg}^{2+}$ and $\mathrm{K}^{+}$(Table 4).

\section{Discussion}

\subsection{Chemical and physical characteristics under beech trees and forest gap}

Our results showed lower $\mathrm{pH}$ values in the uppermost $50 \mathrm{~cm}$ of the soil under Oriental beech trees compared to the open area in the forest gap. Possible sources of $\mathrm{H}^{+}$ions include oxidation of biomass and $\mathrm{NH}_{4}{ }^{+}$, root respiration with the formation of carbonic acid, exudation of organic acids by the roots and/or organic acids produced by incomplete litter decomposition (Guckland 2009). Finzi et al. (1998) and Neirynck et al. (2000) reported lower pH values and base saturation under the canopies of Fagus species compared to Tilia, Fraxinus and Acer species. They attributed this finding to the interspecific differences of the acidification potential of the tree litter. The litter in the forest gap is mainly composed of herbs and grasses, whose palatability for the soil biota is much better compared to litter from beech. Therefore, the mineralisation of the litter in the forest gap is more complete, and fewer organic acids are produced leading to a higher $\mathrm{pH}$ value in the forest gap. This is analogous to what occurs in mixed stands, where the litter quality of different species and the associated base cation recycling through the soil-tree system have important effects on the pattern of soil fertility and soil acidity (Nordén 1994; Rothe and Binkley 2001). Therefore, litter composition can be assumed to be a significant factor in surface soil acidity (Guckland 2009). In accordance with the lower $\mathrm{pH}$ values in the forest, the $\mathrm{CaCO}_{3}$ content in the forest topsoil is lower in comparison to the forest gap. $\mathrm{CaCO}_{3}$ is the primary buffer substance for acidity and is consumed to a higher degree in the uppermost few centimetres of the forest soil.

The higher litter input in the forest and the slower and incomplete mineralisation of the beech litter leads to an approximately three times higher organic matter content of the forest topsoil compared to the topsoil of the forest gap. This difference is also apparent in the subsoil even though on a lower level.

\subsection{Effect of tree canopy and litter on throughfall and litterflow chemistry}

We have shown significant differences in element fluxes in throughfall of Oriental beech forests compared to rainfall for all four elements analysed. Throughfall chemistry is mainly affected by the washing of deposits from the canopy surface, by leaching elements from internal plant tissues and through the uptake of elements in the canopy (Potter 1991). Many studies in the literature have demonstrated higher amounts of $\mathrm{Na}^{+}, \mathrm{K}^{+}, \mathrm{Ca}^{2+}$ and $\mathrm{Mg}^{2+}$ in throughfall compared to rainfall amongst all different climates and forest types (Potter 1991; Chuyong et al. 2004; Tobón et al. 2004a; Duchesne and Houle 2006; Dezzeo and Chacón 2006; Ndakara 2012; Adedeji and Gbadegesin 2012). From all measured cations in our study, the amount of $\mathrm{K}^{+}$in throughfall was the highest and $\mathrm{Mg}^{2+}$ the lowest $\left(\mathrm{K}^{+}>\mathrm{Na}^{+}>\mathrm{Ca}^{2+}>\mathrm{Mg}^{2+}\right)$ which agrees with findings from previous studies (Staelens et al. 2003; André et al. 2008; Van Stan et al. 2012, Habashi et al. 2019). During the observation period, $54.6 \mathrm{~kg} \mathrm{~K}^{+} \mathrm{ha}^{-1}$ entered the canopy layer of the beech forest while more than double this amount entered in the throughfall. The large amount of $\mathrm{K}^{+}$in throughfall is attributed to the higher susceptibility of this cation to canopy leaching compared to $\mathrm{Na}^{+}, \mathrm{Mg}^{2+}$ and $\mathrm{Ca}^{2+}$ (Staelens et al. 2003; André et al. 2008). This susceptibility is the result of the high mobility and leachability of $\mathrm{K}^{+}$in cells near leaf surfaces (Schlesinger 1997; Tobón et al. 2004a), and the fact that it is not tightly bound in structure tissues or enzyme compounds (Draaijers et al. 1996).

Sodium in throughfall is often attributed to atmospheric deposition mainly from sea spray (Parker 1983). Our site is $50 \mathrm{~km}$ from the Caspian Sea and it is reasonable that the high amount of $\mathrm{Na}^{+}$in rainfall $\left(26.3 \mathrm{~kg} \mathrm{ha}^{-1}\right.$ year $\left.^{-1}\right)$ originates from this source. Furthermore, the additional $16.8 \mathrm{~kg} \mathrm{Na}^{+} \mathrm{ha}^{-1}$ year $^{-1}$ in throughfall is attributable to the washing of deposits accumulated on the canopy between precipitation events (Parker 1983; Devlaeminck et al. 2005) and only to a very small degree to canopy leaching, because $\mathrm{Na}^{+}$is only found in low concentrations in leaves (Parker 1983).

Enrichment of $\mathrm{Ca}^{2+}$ and $\mathrm{Mg}^{2+}$ in throughfall after passing through the forest canopy was 18.6 and $2.9 \mathrm{~kg} \mathrm{ha}^{-1}$ year $^{-1}$, respectively, increasing the amount of these cations in throughfall by a factor of 2.9 for $\mathrm{Ca}^{2+}$ and 1.9 for $\mathrm{Mg}^{2+}$ compared to rainfall. This is considerably more $\mathrm{Ca}^{2+}$ and less $\mathrm{Mg}^{2+}$ than Rothe et al. (2002) reported in a comparison of 16 biogeochemical studies in European beech (Fagus sylvatica) stands. They found across all sites, respective factors of 1.9 for $\mathrm{Ca}^{2+}$ and 3.4 for $\mathrm{Mg}^{2+}$. The abovementioned enrichment factor for $\mathrm{Mg}^{2+}$ in our study is comparable to the other cations, with $\mathrm{Ca}^{2+}$ being somewhat higher. The leached amounts of $\mathrm{Ca}^{2+}$ and $\mathrm{Mg}^{2+}$, on the other hand, are considerably lower compared to $\mathrm{Na}^{+}$and $\mathrm{K}^{+}$. Calculated on a molar basis, there were only $0.46 \mathrm{kmol} \mathrm{Ca}^{2+} \mathrm{ha}^{-1}$ year ${ }^{-1}$ and $0.12 \mathrm{kmol} \mathrm{Mg}^{2+} \mathrm{ha}^{-1}$ year $^{-1}$ leached from the canopy compared to $1.5 \mathrm{kmol} \mathrm{K}^{+} \mathrm{ha}^{-1}$ year ${ }^{-1}$. This indicates the lower mobility of $\mathrm{Ca}^{2+}$ and $\mathrm{Mg}^{2+}$ which is due to the binding of $\mathrm{Mg}^{2+}$ in organic molecules, especially chlorophyll, and the fact that $\mathrm{Ca}^{2+}$ is an important constituent of the plant cell wall 
(Kramer and Kozlowski 1979). Mainly for $\mathrm{Mg}^{2+}$, dry deposition may supply more than $80 \%$ to the net throughfall in marine environments (Parker 1983) and the contribution of leaching is less important. This also applies, although to a lesser extent, to $\mathrm{Ca}^{2+}$, given the much lower $\mathrm{Ca}^{2+}$ to $\mathrm{Cl}^{-}$ratio in seawater (e.g. Krumgalz 1982; Nessim et al. 2015).

Throughfall is one important pathway through which base cations reach the forest floor, thus affecting the biogeochemical cycling of forested ecosystems (Augusto et al. 2002). A further significant process is litterfall and the leaching of the litter layer, which import base cations into the mineral soil (Moslehi 2010; Shabani 2013). We have shown that, with the exception for $\mathrm{Na}^{+}$, all fluxes of base cations in litterflow are higher compared to rainfall, although the differences are only statistically significant for $\mathrm{Ca}^{2+}$. In contrast, the fluxes of all measured base cations in litterflow were significantly smaller compared to throughfall. With our sampling design, one can assume that rainfall passes through the canopy layer, a part of rainfall enters the litter layer as throughfall and reaches the mineral topsoil as litterflow. While the base cation fluxes increase in throughfall compared to rainfall, they decrease by passing through the litter layer. This decrease can be ascribed to mainly two processes in the litter layer. The litter layer is biologically the most active layer where soil fauna and microorganisms meet their requirements through the uptake of essential base cations (Golley et al. 1975; Moslehi 2010; Shabani 2013). Besides this biological immobilisation, there is also adsorption of base cations to active surfaces in the litter layer. Obviously, these sinks for base cations are more pronounced than the sources of base cations which are released by desorption and mineralisation. The quantity of leached base cations depends not only on these processes but also on the amount of water percolating through the ecosystem layers. While $73 \%$ of rainfall passes through the canopy layer, there is only $32 \%$ of rainfall or $45 \%$ of throughfall leaving the litter layer. A large quantity of water is retained in the litter layer, and, in addition, water is partly evaporated. The evaporation of water additionally increases the adsorption of base cations in the litter layer (Moslehi 2010). Considering the individual cations in litterflow, $\mathrm{K}^{+}$was the dominant cation in litter leachates followed by $\mathrm{Na}^{+}, \mathrm{Ca}^{2+}$ and $\mathrm{Mg}^{2+}$, which coincides with the composition of throughfall and with findings from other regions in the world (Fujinuma et al. 2005; Johnson-Maynard et al. 2005). Considering the interaction of base cations with the surfaces of the solid phase in the litter layer, $\mathrm{Ca}^{2+}$ and $\mathrm{Mg}^{2+}$ are more tightly adsorbed compared to $\mathrm{K}^{+}$and $\mathrm{Na}^{+}$ (Evangelou and Phillips 2005). Furthermore, base cations are also leached from the decomposing litter (Duivenvoorden and Lips 1995; Tobón et al. 2004a), and by means of faster decomposition, more abundant base cations preferably enter the soil by litterflow (Strobel et al. 2001; Van Nevel et al. 2013). The exchange and leaching of base cations depend on the chemical composition of the plant litter and the concentrations of the individual base cations in the litter (Eaton et al. 1973). Higher leaching of $\mathrm{K}^{+}$in litterflow can be explained by its high mobility and leachability in dead and living plants (Tobón et al. 2004b). Amini (2009) found the substantial release of $\mathrm{K}^{+}$from new fallen leaf litter of Oriental beech by decomposition. Approximately $80 \%$ of the $\mathrm{K}^{+}$in newly fallen leaf litter is released in the first month (Chuyong et al. 2002) while $\mathrm{Ca}^{2+}$ accumulates in the leaf litter during the first 2 years and is slowly released afterwards (Yavitt and Fahey 1986). Therefore, lower $\mathrm{Ca}^{2+}$ and $\mathrm{Mg}^{2+}$ than $\mathrm{K}^{+}$in litterflow leaching can likely be ascribed to (i) their lower concentrations in the leaf litter than $\mathrm{K}^{+}$(Duivenvoorden and Lips 1995), (ii) slower release of $\mathrm{Ca}^{2+}$ and $\mathrm{Mg}^{2+}$ during litter decomposition (Yavitt and Fahey 1986) because of tight bonding in structural tissues or enzyme complexes in comparison to $\mathrm{K}^{+}$(Campo et al. 2000), (iii) uptake by decomposers and immobilisation of $\mathrm{Ca}^{2+}$ and $\mathrm{Mg}^{2+}$ in their microbial biomass (Golley et al. 1975) and (iv) stronger adsorption of divalent $\mathrm{Ca}^{2+}$ and $\mathrm{Mg}^{2+}$ to the solid phase in the litter layer compared to the monovalent $\mathrm{K}^{+}$(Evangelou and Phillips 2005).

Sodium is often considered to be delivered entirely by atmospheric deposition, and to pass through the ecosystem with relatively small amounts being cycled by plants and soil biota (Verstraeten et al. 2012). In accordance with the proximity of the study area to the Caspian Sea, lower levels of $\mathrm{Na}^{+}$in leaves and a more considerable role played by marine depositions in $\mathrm{Na}^{+}$leaching are expected. Thus, the reduction of $\mathrm{Na}^{+}$ leaching in litterflow relative to throughfall cannot be explained by biochemical processes.

\subsection{Effect of canopy and litter on mineral soil solution}

Our results indicate a higher load of $\mathrm{K}^{+}, \mathrm{Na}^{+}$and $\mathrm{Mg}^{2+}$ in the forest soil solution compared to the forest gap, whereas for $\mathrm{Ca}^{2+}$, the opposite is true. The interactions between soil solution and solid phase are different for the various cations and soil depths. The amounts of $\mathrm{K}^{+}$and $\mathrm{Mg}^{2+}$ leached from the topsoil and subsoil are greater in the forest compared to the forest gap by a factor of 1.4 to 2.4, although the differences are only significant for $\mathrm{K}^{+}$at both soil depths. This can mainly be attributed to canopy leaching and the considerable increase in a load of water percolating through the vegetation layer. The higher amount of water percolating through the soil in the forest compared to the forest gap (408 mm vs. $327 \mathrm{~mm}$ in topsoil, $336 \mathrm{~mm}$ vs. $239 \mathrm{~mm}$ in subsoil) may also partly explain the higher leaching of base cations in the forest. These differences in the amount of percolating water could be attributed to the highly varying slope of the site (35\% in average) and the high amount of clay in the subsoil which leads to lateral water flow with high spatial variability. The higher amount of percolating water in the topsoil of the forest compared to the litter layer may similarly be explained. In the litter 
layer, the horizontally layered leaves may lead to an even higher lateral flow with huge spatial variability.

In the case of $\mathrm{K}^{+}, 65.8 \mathrm{~kg} \mathrm{ha}^{-1}$ year ${ }^{-1}$ enters the top mineral soil as litterflow in the forest, whereas in the forest gap the $\mathrm{K}^{+}$ input to the topsoil by rainfall only amounts to $54.6 \mathrm{~kg} \mathrm{ha}^{-1}$ year ${ }^{-1}$, a difference of $11.2 \mathrm{~kg}^{-1} \mathrm{ha}^{-1}$ year $^{-1}$. This difference increases to $18.7 \mathrm{~kg} \mathrm{ha}^{-1}$ year $^{-1}$ in the water leaving the topsoil (TSF-TSO) and still amounts to $16.3 \mathrm{~kg} \mathrm{ha}^{-1}$ year $^{-1}$ in the water leaving the subsoil (SSF$\mathrm{SSO}$ ). The transfer coefficients between water input and topsoil, calculated as the ratio of TSF/LF for the forest and TSO/ $\mathrm{RF}$ for the forest gap, are both very similar $(0.7$ for the forest and 0.6 for the forest gap), meaning that the extent of the interactions between percolating water and topsoil are similar for both areas. The same is true for the topsoil-subsoil transfer coefficients. Transfer coefficients lower than 1 mean that $\mathrm{K}^{+}$ disappears from the soil solution by passing through the mineral topsoil. Potassium adsorbs to the soil surface and/or is taken up by the vegetation and soil fauna. Potassium is a highly mobile base cation in forests, which cycles easily between the soil and vegetation (Frank and Stuanes 2003). However, the older the organic matter is, the less $\mathrm{K}^{+}$will be released to the soil water. As mentioned above, $\mathrm{K}^{+}$is easily leached from living plant material and $80 \%$ of $\mathrm{K}^{+}$from the litter is released during the first month (Chuyong et al. 2002). Therefore, the sinks which remove $\mathrm{K}^{+}$from the soil solution (mainly adsorption and biological fixation) dominate the sources which supply $\mathrm{K}^{+}$to the soil solution (mainly desorption and leaching of soil organic matter) in both the topsoil and the subsoil of the forest and the forest gap.

The dissolved $\mathrm{Mg}^{2+}$ behaved in the aboveground part of the Oriental beech forest similarly to $\mathrm{Ca}^{2+}$. Magnesium is enriched in litterflow compared to rainfall by a factor of 1.4 due to canopy leaching, which means that $4.5 \mathrm{~kg} \mathrm{Mg}^{2+} \mathrm{ha}^{-1}$ year $^{-1}$ enter the topsoil in the forest compared to $3.2 \mathrm{~kg} \mathrm{ha}^{-1}$ year $^{-1}$ in the forest gap (a difference of $1.3 \mathrm{~kg} \mathrm{ha}^{-1}$ year $^{-1}$ ). This difference increases steadily to $2 \mathrm{~kg} \mathrm{ha}^{-1}$ year $^{-1}$ in the topsoil and $3.8 \mathrm{~kg} \mathrm{ha}^{-1}$ year $^{-1}$ in the subsoil. The amount of leached $\mathrm{Mg}^{2+}$ increases from the litter layer to the topsoil. While the transfer coefficients in the topsoil are similar for the forest and the forest gap, more $\mathrm{Mg}^{2+}$ is leached in the forest in terms of absolute quantities. The transfer coefficients are higher than 1 , which means that $\mathrm{Mg}^{2+}$ is released to the soil solution in the top mineral soil. On average, the molar concentrations of $\mathrm{Mg}^{2+}$ in rainfall, litterflow and the soil solution of topsoils were $2 \times 10^{-5} \mathrm{Mol} \mathrm{L}^{-1}, 6 \times$ $10^{-5} \mathrm{Mol} \mathrm{l}^{-1}$ and $8 \times 10^{-5} \mathrm{Mol} \mathrm{L}^{-1}$, respectively. The respective concentrations for $\mathrm{K}^{+}$were $1.4 \times 10^{-4} \mathrm{Mol} \mathrm{L}^{-1}, 5.3 \times$ $10^{-4} \mathrm{Mol} \mathrm{L}^{-1}$ and $3.0 \times 10^{-4} \mathrm{Mol} \mathrm{L}^{-1}$, respectively (data not shown). The much lower concentrations of $\mathrm{Mg}^{2+}$ mean that in contact with the mineral soil, a new equilibrium is established which tends to desorb $\mathrm{Mg}^{2+}$ with greater likelihood than $\mathrm{K}^{+}$ due to the concentration differences. Furthermore, $\mathrm{Ca}^{2+}$ and
$\mathrm{Mg}^{2+}$ are more strongly bound in plant cells and, during decomposition, they accumulate in the leaf litter during the first 1 to 2 years and thereafter are slowly released (Yavitt and Fahey 1986). This points to older litter and organic matter in the topsoil of the forest as a continuous source of $\mathrm{Mg}^{2+}$ released to the soil water. This is also mirrored in the subsoil of the forest where higher amounts of organic matter are responsible for the greater leaching of $\mathrm{Mg}^{2+}$ compared to the forest gap, although the transfer coefficients SS/TS are less than 1 .

The enrichment of $\mathrm{Ca}^{2+}$ in litterflow compared to rainfall by a factor of 1.5 due to canopy leaching means that $14.2 \mathrm{~kg} \mathrm{ha}^{-1}$ year $^{-1}$ enter the topsoil in the forest compared to $9.5 \mathrm{~kg} \mathrm{ha}^{-1}$ year $^{-1}$ in the forest gap (a difference of $4.7 \mathrm{~kg} \mathrm{ha}^{-1}$ year ${ }^{-1}$ ). In contrast to $\mathrm{K}^{+}$but similar to $\mathrm{Mg}^{2+}$, the transfer coefficients for $\mathrm{Ca}^{2+}$ between water input and topsoil are higher than 1 (2.6 for the forest, 6.0 for the forest gap). The increase in dissolved $\mathrm{Ca}^{2+}$ in the soil solution of the topsoil is mainly due to the carbonate content in the soil (Schlesinger 1997), which is distinctly higher in the forest gap topsoil. In the forest subsoil, the leached amounts of $\mathrm{Ca}^{2+}$ are similar to those in the topsoil, while in the forest gap, they are reduced to $60 \%$ of the amount in the topsoil. The reason for this could be adsorption or precipitation of calcium, uptake of $\mathrm{Ca}^{2+}$ by soil fauna and vegetation (Swift and Anderson 1989), or a loss of $\mathrm{Ca}^{2+}$ by lateral water flow. Berger et al. (2009a, b) showed that nutrient leaching through the soil is not simply a 'wash through' but is mediated by a complex set of reactions within the plant-soil system.

Other than for the elements $\mathrm{K}^{+}, \mathrm{Ca}^{2+}$ and $\mathrm{Mg}^{2+}$, the plant demand for $\mathrm{Na}^{+}$is small, and the interaction between solution and soil surfaces is weak. Therefore, this element could be seen as a more or less inert tracer, and the ratios and transfer coefficients between the various layers are possibly symptomatic of the uncertainty in the experimental design, with the exception of the enrichment in throughfall, which can be interpreted as leaching of deposited $\mathrm{Na}^{+}$during rain-free periods.

\subsection{Conclusions}

From the comparison of water fluxes in an Oriental beech forest to those in an unforested gap nearby, it can be inferred that base cation quantities and fluxes are considerably greater in throughfall and litterflow in Oriental beech forests, which imply that these are important pathways for base cation inputs into the soil. Larger amounts of base cations in throughfall are caused by canopy exchange processes and atmospheric deposition from the Caspian Sea.

While base cation fluxes are greater in throughfall compared to rainfall, they decrease when passing through the litter layer due to biological immobilisation and physicochemical adsorption. Water evaporation from the litter layer further increases the adsorption of base cations in the litter layer. In the 
mineral soil, differences in leached quantities of base cations are mainly due to stronger adsorption of divalent compared to monovalent cations and different leachability and release during decomposition of organic matter.

Our results show that in the process of base cation cycling, Oriental beech trees return considerable amounts of these elements to the soil by throughfall and litterflow, and in this way help to maintain the soil fertility and forest sustainability. Amongst throughfall, litterflow, topsoil and subsoil, the contribution of throughfall to biogeochemical cycling is considerable, and thereby plays a key role in the biogeochemical cycle and plant growth. Thus, when selection cutting, timber marking and thinning, forest managers must consider the return of base cations through throughfall and litterflow in Oriental beech forests in order to account for their role in the nutrient cycling and sustainable nutrition of forests.

Acknowledgements The authors express their gratitude to the Gorgan University of Agricultural Science and Natural Resources for scientific and financial support. We thank Curtis Gautschi for improving the English text and two anonymous reviewers for valuable comments that significantly improved the manuscript. The data are deposited in the EnviDat database (www.envidat.ch) under 'Base cation dynamics in Oriental beech forest' (doi: https://doi.org/10.16904/envidat.66).

Funding This work is part of the thesis of Maryam Moslehi and was funded by the Gorgan University of Agricultural Science and Natural Resources, Golestan Province, Gorgan, Shahid Beheshti, Iran.

Data availability The datasets generated and/or analysed during the current study are available in the EnviDat (www.envidat.ch) database (Moslehi et al. 2019) at https://doi.org/10.16904/envidat.66.

\section{Compliance with ethical standards}

Conflict of interest The authors declare that they have no conflicts of interest.

\section{References}

Abbasian P, Attarod P, Dolatshahi A, Sadeghi SMM (2014) Concentration, flux and enrichment of elements in Fagus orientalis in Kelardasht, north of Iran. Bull Environ Pharmacol Life Sci 3:4952

Adedeji OH, Gbadegesin AS (2012) Base cation leaching from the canopy of a rubber (Hevea brasiliensis (Willd.) Muell.-Arg.) plantation at Ikenne, southwest Nigeria. Ethiop J Environ Stud Manag 5:384 390. https://doi.org/10.4314/ejesm.v5i4.7

Amini R (2009) Nutrient dynamics of hornbeam-beech leaf litter in the organic matter of the mixed beech forest, Shastkolate, Gorgan. Dissertation, Gorgan University of Agricultural Sciences and Natural Resources

André F, Jonard M, Ponette Q (2008) Spatial and temporal patterns of throughfall chemistry within a temperate mixed oak-beech stand. Sci Total Environ 397:215-228. https://doi.org/10.1016/j.scitotenv. 2008.02.043
Augusto L, Ranger J, Binkley D, Rothe A (2002) Impact of several common tree species of European temperate forests on soil fertility. Ann For Sci 59:233-253. https://doi.org/10.1051/forest:2002020

Berger TW, Untersteiner H, Toplitzer M, Neubauer C (2009a) Nutrient fluxes in pure and mixed stands of spruce (Picea abies) and beech (Fagus sylvatica). Plant Soil 322:317-342. https://doi.org/10.1007/ s11104-009-9918-z

Berger TW, Inselsbacher E, Mutsch F, Pfeffer M (2009b) Nutrient cycling and soil leaching in eighteen pure and mixed stands of beech (Fagus sylvatica) and spruce (Picea abies). For Ecol Manag 258:25782592. https://doi.org/10.1016/j.foreco.2009.09.014

Bruijnzeel LA (2001) Hydrology of tropical montane cloud forests: a reassessment. Land Use Water Resour Res 1:1.1-1.18

Campo J, Manuel MJ, Vicotr J, Jaramollo, Angelina MY (2000) Calcium, potassium and magnesium cycling in a Mexican tropical dry forest ecosystem. Biogeochemistry 49:21-36

Chuyong GB, Newbery DM, Songwe NC (2002) Litter breakdown and mineralization in a central African rain forest dominated by ectomycorrhizal trees. Biogeochemistry 61:73-94

Chuyong GB, Newbery DM, Songwe NC (2004) Rainfall input, throughfall and stemflow of nutrients in a central African rain forest dominated by ectomycorrhizal trees. Biogeochemistry 67:73-91. https://doi.org/10.1023/B:BIOG.0000015316.90198.cf

Devlaeminck R, De Schrijver A, Hermy M (2005) Variation in throughfall deposition across a deciduous beech (Fagus sylvatica L) forest edge in Flanders. Sci Total Environ 337:241-252. https:// doi.org/10.1016/j.scitotenv.2004.07.005

Dewis J, Freitas F (1970) Physical and chemical methods of soil and water analysis. FAO Soils Bulletin, No 10, Rome

Dezzeo N, Chacón N (2006) Nutrient fluxes in incident rainfall, throughfall and stemflow in adjacent primary and secondary forests of the Gran Sabana, southern Venezuela. For Ecol Manag 234:218226

Draaijers GPJ, Erisman JW, Spranger T, Wyers GP (1996) The application of throughfall measurements for atmospheric deposition monitoring. Atmos Environ 30:3349-3361. https://doi.org/10.1016/ 1352-2310(96)00030-1

Duchesne L, Houle D (2006) Base cation cycling in a pristine watershed of the Canadian boreal forest. Biogeochemistry 78:195-216

Duivenvoorden JF, Lips JM (1995) A land-ecological study of soils, vegetation, and plant diversity in Colombian Amazonia. The Tropenbos Foundation, Wageningen

Eaton JS, Likens GE, Bormann FH (1973) Throughfall and stemflow chemistry in a northern hardwood forest. J Ecol 61:495-508. https://doi.org/10.2307/2259041

Evangelou VP, Phillips RE (2005) Cation exchange in soils. In: Tabatabai MA, Sparks DL (eds) Chemical processes in soils, vol 8. SSSA Book Series, pp 343-410

Finzi AC, Canham CD, Van Breemen N (1998) Canopy tree-soil interactions within temperate forests: species effects on $\mathrm{pH}$ and cations. Ecol Appl 8:447-454. https://doi.org/10.1890/10510761(1998)008[0447:CTSIWT]2.0.CO;2

Frank J, Stuanes AO (2003) Short-term effects of liming and vitality fertilization on forest soil and nutrient leaching in a Scots pine ecosystem in Norway. For Ecol Manag 176:371-386. https://doi.org/ 10.1016/S0378-1127(02)00285-2

Fujinuma R, Bockheim J, Balster N (2005) Base-cation cycling by individual tree species in old-growth forests of upper Michigan, USA. Biogeochemistry 74:357-376

Gee GW, Bauder JW (1986) Particle-size analysis. In: Klute A (ed) Methods of soil analysis, part I, physical and mineralogical methods. American Society of Agronomy and Soil Science Society of America. Agronomy monograph no. 9 (2nd Edition). Madison, WI, pp 383-411 
Ghorbani S, Rahmani R (2009) Estimating of interception loss, stemflow and throughfall in a natural stand of Oriental beech (Shastkalateh forest). Iran J For Pop Res 16:638-648

Golley FB, McGinnis JT, Clements RG, Child GI, Deuver MJ (1975) Mineral cycling in a tropical moist forest ecosystem. University of Georgia, Athens

Guckland A (2009) Nutrient stocks, acidity, processes of N transformation and net uptake of methane in soils of a temperate deciduous forest with different abundance of beech (Fagus sylvatica L). Dissertation, Göttingen University

Habashi H, Moslehi M, Shabani E, Pypker T, Rahmani R (2019) Chemical content and seasonal variation of throughfall and litterflow under individual trees in the Hyrcanian forest of Iran. J Sustain For 38:183-197. https://doi.org/10.1080/10549811.2018. 1554496

IUSS Working Group WRB (2006) World reference base for soil resources 2006. World Soil Resources Reports No. 103. FAO, Rome

Johnson-Maynard JL, Graham RC, Shouse PJ, Quideau SA (2005) Base cation and silicon biogeochemistry under pine and scrub oak monocultures: implications for weathering rates. Geoderma 126:353-365. https://doi.org/10.1016/j.geoderma.2004.10.007

Kramer PJ, Kozlowski TT (1979) Physiology of woody plants. Academic Press, New York

Krumgalz BS (1982) Calcium distribution in the world ocean waters. Oceanol Acta 5:121-128

Liu W, Fox JED, Xu Z (2002) Nutrient fluxes in bulk precipitation, throughfall and stemflow in montane subtropical moist forest on Ailao Mountains in Yunnan, southwest China. J Trop Ecol 18: 527-548. https://doi.org/10.1017/S0266467402002353

Moslehi M (2010) The effect of beech species on base-cation dynamics in mixed Hyrcanian beech forest, Shastkolate. Dissertation, Gorgan University of Agricultural Sciences and Natural Resources

Moslehi M; Habashi H; Khormali F; Ahmadi A; Brunner I; Zimmermann S (2019). Base cation dynamics in an Oriental beech forest. V 11 April 2019. EnviDat. [Dataset]. https://doi.org/10.16904/envidat.66

Muoghalu JI, Oakhumen A (2000) Nutrient content of incident rainfall, throughfall and stemflow in a Nigerian secondary lowland rainforest. Appl Veg Sci 3:181-188. https://doi.org/10.2307/ 1478996

Návar J, Méndez J, González J, Gonzalez H (2009) Gross precipitation and throughfall chemistry in legume species planted in northeastern Mexico. Plant Soil 318:15-26

Ndakara OE (2012) Throughfall, stemflow and litterfall nutrient flux isolated stands of Peseagratissima in a moist tropical rainforest region, southern Nigeria. J Phys Environ Sci Res 1:5-14

Neirynck J, Mirtcheva S, Sioen G, Lust N (2000) Impact of Tilia platyphyllos Scop., Fraxinus excelsior L., L., Quercus robur L. and Fagus sylvatica L. on earthworm biomass and physicochemical properties of a loamy topsoil. For Ecol Manag 133:275286

Nelson DW, Sommers LE (1996) Total carbon, organic carbon, and organic matter. In: Bigham JM (ed) Methods of Soil Analysis, Part 3, Chemical methods. Soil Science Society of America and American Society of Agronomy. SSSA Book Series no.5. Madison, WI, pp 961-1010

Nessim RB, Tadros HRZ, Taleb AEA, Moawad MN (2015) Chemistry of the Egyptian Mediterranean coastal waters. Egypt J Aquat Res 41: $1-10$

Nordén U (1994) Influence of tree species on acidification and mineral pools in deciduous forest soils of South Sweden. Water Air Soil Pollut 76:363-381. https://doi.org/10.1007/BF00482713

Parker GG (1983) Throughfall and stemflow in the forest nutrient cycle. Adv Ecol Res 13:57-133. https://doi.org/10.1016/S0065-2504(08) 60108-7

Parsapajouh D (1974) Qualité du bois de Fagus orientalis de l'Elbourz (Iran). Rev For Fr 6:464-471
Potter CS (1991) Nutrient leaching from Acer rubrum leaves by experimental acid rainfall. Can J For Res 21:222-229. https://doi.org/10. 1139/x91-027

Rothe A, Binkley D (2001) Nutritional interactions in mixed species forests: a synthesis. Can J For Res 31:1855-1870. https://doi.org/ $10.1139 / \mathrm{x} 01-120$

Rothe A, Huber C, Kreutzer K, Weis W (2002) Deposition and soil leaching in stands of Norway spruce and European beech: results from the Höglwald research in comparison with other European case studies. Plant Soil 240:33-45. https://doi.org/10.1023/A: 1015846906956

Salehi M, Zahedi Amiri G, Attarod P, Salehi A, Brunner I, Schleppi P, Thimonier A (2016) Seasonal variations of throughfall chemistry in pure and mixed stands of Oriental beech (Fagus orientalis Lipsky) in Hyrcanian forests (Iran). Ann For Sci 73:371-380. https://doi.org/ 10.1007/s13595-015-0525-2

Schaefer DA, Reiners WA, Olson RK (1988) Factors controlling the chemical alteration of throughfall in a subalpine balsam fir canopy. Environ Exp Bot 28:175-189. https://doi.org/10.1016/00988472(88)90027-5

Schlesinger WH (1997) Biogeochemistry: an analysis of global changes. Academic Press, San Diego

Schoeneberger PJ, Wysocki DA, Benham EC, Soil Survey Staff (2012) Field book for describing and sampling soils, version 3.0. Natural Resources Conservation Service, National Soil Survey Center, Lincoln

Shabani E (2013) Base cation dynamic in throughfall and forest floor leaching of Acer velutinum (Velvet maple), Carpinus betulus (hornbeam) and Quercus castanifolia (Chestnut leaved oak) in the mixed Hornbeam-Ironwood forest stand. Dissertation, Gorgan University of Agricultural Sciences and Natural Resources

Smith JL, Doran JW (1996) Measurement and use of $\mathrm{pH}$ and electrical conductivity for soil quality analysis. In: Doran JW, Jones AJ (eds) Methods for assessing soil quality. SSSA Species Publication. 49. Madison, WI, pp 169-185

Soil Survey Staff (2010) Keys to soil taxonomy. US Department of Agriculture, Washington

Staelens J, De Schrijver A, Oyarzún C, Lust N (2003) Comparison of dry deposition and canopy exchange of base cations in temperate hardwood forests in Flanders and Chile. Gayana Bot 60:9-16

Staelens J, De Schrijver A, Verheyen K, Verhoest NEC (2008) Rainfall partitioning into throughfall, stemflow, and interception within a single beech (Fagus sylvatica L.) canopy: influence of foliation, rain event characteristics, and meteorology. Hydrol Process 22:33-45. https://doi.org/10.1002/hyp.6610

Strobel BW, Bruun Hansen HC, Borggaard OK, Andersen MK, RaulundRasmussen K (2001) Composition and reactivity of DOC in forest floor soil solutions in relation to tree species and soil type. Biogeochemistry 56:1-26

Swift MJ, Anderson JM (1989) Decomposition. In: Lieth H, Werger MJA (eds) Tropical rain forest ecosystems -biogeographical and ecological studies, ecosystems of the world 14B. Elsevier, Amsterdam, pp $547-569$

Tobón C, Sevink J, Verstraten JM (2004a) Solute fluxes in throughfall and stemflow in four forest ecosystems in northwest Amazonia. Biogeochemistry 70:1-25

Tobón C, Sevink J, Verstraten JM (2004b) Litterflow chemistry and nutrient uptake from the forest floor in northwest Amazonian forest ecosystems. Biogeochemistry 69:315-339. https://doi.org/10.1023/ B:BIOG.0000031051.29323.27

Van Nevel L, Mertens J, De Schrijver A, Baeten L, De Neve S, Tack FMG, Meers E, Verheyen K (2013) Forest floor leachate fluxes under six different tree species on a metal contaminated site. Sci Total Environ 447:99-107. https://doi.org/10.1016/j.scitotenv. 2012.12.074 
Van Stan JT, Levia DF Jr, Inamdar SP, Lepori-Bui M, Mitchell MJ (2012) The effects of phenoseason and storm characteristics on throughfall solute washoff and leaching dynamics from a temperate deciduous forest canopy. Sci Total Environ 430:48-58. https://doi.org/10.1016/ j.scitotenv.2012.04.060

Verstraeten A, Neirink J, Genouw G, Cools N, Roskams P, Hens M (2012) Impact of declining atmospheric deposition on forest soil solution chemistry in Flanders Belgium. Atmos Environ 62:50-63

Ward RC, Robinson M (2000) Principles of hydrology. McGraw Hill Publishing Company, London
Yavitt JB, Fahey TJ (1986) Litter decay and leaching from the forest floor in Pinus contorta (Lodgepole pine) ecosystems. J Ecol 74:525-245. https://doi.org/10.2307/2260272

Zarinkafsh M (1992) Forestry soil, 1st edn. Tehran Research Institute of Forests and Rangelands press, Tehran

Publisher's note Springer Nature remains neutral with regard to jurisdictional claims in published maps and institutional affiliations. 